\title{
La novela histórica: una contradicción realizada
}

\author{
Augusto Escobar MesA*
}

Resumen

El propósito de este artículo es mostrar el origen y relación armónica de dos géneros, ficción e historia, que confluyen no sin contradicciones armónicamente en uno. Interesa indicar el origen de la novela histórica discutido por críticos, literatos e historiadores y su aporte significativo en el dominio literario y también fuente valiosa para los historiadores sociales, de las ideas y mentalidades. Al inicio de este artículo y a partir de algunos presupuestos conceptuales e históricos (Aristóteles, Menéndez Pelayo, Alfonso Reyes, Ricoeur), se muestra la efectiva relación entre historia y ficción en su doble condición: ser géneros discursivos y contar con una historia. En la segunda parte se observa el reconocimiento que hace buena parte de los nuevos historiadores (Chaunu, Ariés, Le Roy-Ladurie, Jauss) al relato literario como una de sus fuentes en la construcción del discurso histórico y de la historia como discurso narrativo que permite, de nuevo, hacer una revaloración de la novela histórica.

Palabras clave

Novela histórica, hermenéutica, discurso narrativo, Menéndez Pelayo, Alfonso Reyes, Ricoeur, Jauss, historia y ficción.

En una carta a Miss Harkness en 1888, Engels sostiene que La comedia bumana de Balzac es obra de "un maestro del realismo" por la manera de describir la sociedad francesa y en particular del mundo

* Profesor-investigador. Universidad de Antioquia. 
parisino de la primera mitad del siglo XIX. Ningún otro texto, según el pensador alemán, muestra tan claramente el ascenso de la burguesía a costa de una aristocracia en decadencia. Los últimos vestigios de esa sociedad aristocrática, ejemplar para Balzac, sucumben poco a poco, y muy a pesar de éste, ante "la intrusión del arribista vulgar repleto de dinero o han sido corrompidos por él"; la gran señora cede el lugar a la "burguesa que se procura un marido con el fin de tener dinero o afeites". No escatima Engels en afirmar que en esa "perpetua elegía" de la sociedad francesa de la que Balzac "deplora la descomposición irremediable de la alta sociedad", "he aprendido más, incluso en lo que concierne a los detalles económicos (por ejemplo, la redistribución de la propiedad real y personal tras la revolución), que en todos los libros de los historiadores, economistas, estadísticos profesionales de la época, todos juntos" (Marx 153, 154).

Cuarenta años después (1929), el historiador holandés J. Huizinga en su libro El concepto de la historia, afirma que "la literatura es, lo mismo que la ciencia, una forma de conocimiento de la cultura que la engendra [...]. La materia plástica de la literatura ha sido y es en todos los tiempos un mundo de formas que es, en el fondo, un mundo histórico" (41). ${ }^{1}$ En la década siguiente en el texto La idea de la historia (1936), Colingwood considera que es lugar común decir que la historia tiene que emplear la imaginación. Para este filósofo de la historia, la imaginación es una "facultad ciega pero indispensable sin la cual, como Kant ha demostrado, no podríamos percibir el mundo que nos circunda, es un indispensable de la misma manera para la historia" (234). Al final de los años cuarenta, el francés Lucien Fevre (Combates por la historia 1949) opina que la historia debe hacerse con documentos escritos si existen, pero cuando no, el historiador debe recurrir a su ingenio "para fabricar su miel, a falta de las flores habitualmente usadas", es decir, palabras, signos, paisajes, ladrillos, formas de campos y malas hierbas [...], eclipses lunares y colleras de los caballos de tiro [...]. Con todo

1 Para este historiador europeo no hay cultura que no viva de las imágenes del pasado que afectan la cultura del presente, y esas imágenes "revisten siempre por principio diversas formas, sin que esto destruya su carácter común, que es el ser 'historia' para la cultura de la que brotan" (38). 
eso que, perteneciendo al hombre, depende del hombre, sirve al hombre, expresa al hombre, demuestra la presencia, la actividad, los gustos y los modos de ser del hombre" (cit. en González 108).

Treinta años después y previa y larga reflexión, Gadamer sostiene en su notable libro Verdad y método que "la existencia humana es un 'Dasein' histórico", porque como lo comenta el hermeneuta e historiador alemán Kosellek, siempre está "orientado hacia la comprensión del mundo que es a la vez aprehendido y constituido lingüísticamente en el mismo acto. La remisión de toda experiencia del mundo a su interpretación del mundo es cooriginaria con la posibilidad de su expresión lingüística y, por consiguiente, como toda lengua, es también histórica" (86).

Este breve barrido por seis representativos pensadores de la cultura y la historia nos sirve para sostener la estrecha y cómplice interacción de la ficción con la historia y de la historia con la ficción. Mucho se ha escrito y discutido sobre la "legitimidad"2 de la novela histórica desde el surgimiento y desarrollo de este nuevo género a finales del siglo XVIII con la llegada del romanticismo. Cada día ingresan nuevos artículos o comentarios a los varios miles registrados en el sistema universal de la web y, sin embargo, es difícil encontrar artículos teóricos consistentes que sustenten lo aplicado; es decir, lo que los articulistas hacen es mostrar casi siempre que tal o cual novela, relato o crónica literaria hacen parte de la llamada novela histórica tradicional o de la nueva novela histórica, o cabalgan entre ambas, pero no son claras las diferencias entre una denominación u otra. En la mayoría de los casos se atienen a caracterizaciones canónicas que se han vuelto lugar común. En esta circunstancia, en vez de hacer avanzar la discusión sobre el tema, lo que hacen es reforzar el estereotipo y garantizar un mimetismo que atenta contra el sub o nuevo género. Lo contrario ocurre con los estudios exclusivamente teóricos, sobre todo desde la hermenéutica (Ricœur, Gadamer, Koselleck, White) y la filosofía analítica (Veyne, Danto), que se han interesado por la relación en-

2 Ya en 1895 Menéndez Pelayo habla de esa discusión y sostiene que ella se extiende igualmente al drama histórico y a "todas las composiciones mixtas de historia y de invención, entre las cuales, a par del drama, logra la novela histórica muy singular importancia" (Obras 2: 33). 
tre ficción e historia. ${ }^{3}$ Para estas corrientes de pensamiento el interés no es tanto la aplicación en la llamada novela histórica en cuanto al funcionamiento de dos géneros que confluyen en uno y en su propuesta estética, sino en cuanto a la estructura o recurso común en ambos: narrar.

\section{Dos géneros en uno: acercamiento histórico}

El propósito de este artículo es mostrar el origen y relación armónica de dos géneros (ficción e historia) que confluyen, no sin contradicciones y contradictores, armónicamente en uno, e indicar cómo la novela histórica constituye un aporte al dominio literario y es fuente valiosa para los historiadores sociales, de las ideas y mentalidades. En la parte inicial se aludirá a la conciliada y efectiva relación entre historia y ficción debido no sólo a su condición de géneros discursivos, sino también por nuestra historicidad que es llevada al lenguaje. En la segunda parte se advierte el reconocimiento que hace buena parte de los nuevos historiadores al relato literario como una de sus fuentes en la construcción del discurso histórico, biográfico, autobiográfico, social, de formación y aún de la novela histórica y de la historia como discurso narrativo.

Siguiendo a Aristóteles en la Retórica (libro III, cap. 13), este estudio consta de dos partes, una es la exposición de la cuestión o problema, la novela histórica o la relación entre historia y novela, y otra es la demostración o la prueba de la cosa, es decir, la vigencia de dicha novela desde la literatura y desde la historia, con breves alusiones -como aplicación- a la literatura colombiana. Para este último no queremos traer como prueba ${ }^{4}$ un repertorio de obras

3 Desde una perspectiva marxista y anterior a los citados, Lukács realizó en su libro La novela histórica uno de los primeros estudios teóricos sobre este género.

4 Prueba entendida en doble sentido: como demostración y como elemento estructurante en la novela. Boves Naves (59-103) señala la prueba como idea y recurso que permite tramar, articular la diégesis y, a su vez, diferenciar la épica de la novela. Mientras el héroe épico representa una visión colectiva del mundo (valores religiosos, culturales, sociales, morales, ideológicos), cuyos valores comparte él y su sociedad, es decir, es un héroe colectivo; en la novela tenemos a un héroe individual, fragmentado, problematizado, sometido a muchas pruebas pa- 
literarias hispanoamericanas que certifiquen su existencia como género tanto de la novela histórica tradicional como de la nueva novela histórica, ya que de ello y a manera de inventario se ha ocupado Seymour Menton en La nueva novela histórica de la América Latina, 1979-1992 (1993).5 Más bien pretendemos hacer una reflexión de la relación entre estos dos géneros que da lugar a uno nuevo, pero cuya historia comienza en los albores del siglo XIX, o quizás antes, si se acepta que toda las grandes obras épicas -O "células de la conciencia" como las llama Pierre Chaunu (14)- de la literatura universal desde los griegos hasta el Renacimiento y más allá, son grandes murales de las sociedades e imperios que un día fueron. Las epopeyas griegas y de otras latitudes son, para el citado historiador francés, las formas más antiguas de "preservación de la memoria" (14). Siguiendo con esta idea, el ensayista mexicano Alfonso Reyes sostiene que: "historia y literatura se mecieron juntas en la cuna de la mitología; y ésta no acierta a distinguir -ni le importa- el hecho de lo hechizo" (85).

Con la novela histórica del siglo XIX tiene lugar el surgimiento de una forma expresiva que para unos es algo híbrido, para otros un subgénero y para algunos más un verdadero género que integra dos disciplinas complementarias. Esto último fue posible con los aportes del romanticismo cuando proclama, como uno de sus decálogos, la disolución o libertad de uso y combinación de géneros que se habían conservado casi puros desde la Poética de Aristóteles. El romanticismo se pronuncia por esa disolución ante la sujeción y prescripción del neoclasicismo. Muy temprano los alemanes H. G. Gerstenberg y Lessing, bajo la influencia del "Sturm und Drang" ("tormenta y deseo", de 1770 a 1780), defienden esa postura. Mientras el primero afirma: "fuera con las clasificaciones del drama. Llamadlas como queráis: plays, history, tragedy, tragicomedy, comedy, yo las llamaré cuadros vivos de la naturaleza moral" (cit. en Wellek, 209), Lessing se pregunta: ¿qué es lo que se pretende con la mezcla de géneros? Para él está bien que se los separe cuan-

ra demostrar un orden particular de valores, casi siempre en cuestión.

${ }^{5}$ Este crítico trae un listado de casi 400 novelas históricas publicadas en Latinoamérica en poco más de medio siglo a partir de la novela corte, El reino de este mundo (1949), de Alejo Carpentier. 
do se los estudie en los libros de texto, "pero cuando un genio con alto designio hace confluir varios géneros en una sola y misma obra, uno se olvida del libro de texto y mira simplemente si ha alcanzado su propósito" (cit. en Garasa 156). Víctor Hugo va más allá cuando en el prefacio a su drama Cromwell (1827) sostiene que se le debe aplicar el martillo no sólo a las teorías, sino también a las poéticas y a los sistemas. Para el poeta y novelista francés no debe haber reglas ni modelos, únicamente las leyes generales de la naturaleza que giran alrededor del arte en general y aquellas particulares que en cada obra derivan de las condiciones propias de cada individuo creador (Michaud 107).

\section{La novela histórica: de oxímoron a contradicción realizada}

En el mismo enunciado de novela histórica encontramos un elemento indicial que remite tanto a un oxímoron como a un juego de contrarios y, también, a una unidad genérica. En relación con lo primero, las dos palabras tendrían significado opuesto debido a que novela remite a hechos ficticios, imaginados, en cambio historia se refiere a hechos reales, comprobables, con alto grado de veracidad (Jitrik 9-10); sin embargo, el oxímoron funciona tanto como una unidad significante y significativa que como figura retórica (unidad de contrarios con sentido siempre sugerido); igual pasa con el género llamado novela histórica. En el nuevo género existe lo uno (historia) en el otro (ficción) por la combinación armónica y la participación de ambos. Con respecto a lo de juego de contrarios opera éste por la llamada ley de contrarios cuya premisa, como principio filosófico de contradicción, fue formulada tempranamente por Parménides al sostener que "algo no puede ser y no ser a la vez”, idea que proviene de Heráclito cuando sostenía que el movimiento era pero al instante dejaba de ser para ser otra cosa o, también, dicho de otra manera: "unido el todo y el no-todo, lo que se junta y lo que se separa, lo consonante y lo disonante; hácese con el todo uno, y con el uno todo" (cit. en Fouillée 63); a esto se llama la conciliación de las diferencias que finalmente genera una "armonía oculta" y que Heráclito bien lo precisa así: "Todo, al dividirse, se reúne, como la armonía del arco y la lira” (idem). 
Volviendo a lo de la novela histórica, la novela es por naturaleza ficcional, algo "inventado" y, en consecuencia, no es historia ni representación objetiva y no tiene que suministrar pruebas, es imaginación y por ende, según Ricœur, "depósito de las tradiciones orales y escritas" (1: 135); en cambio, la historia no puede ser algo imaginario porque dejaría de ser lo que es, realidad demostrable para la que los documentos y los archivos son "fuentes de verificación o falsación" (135) luego, se establecería la contradicción en la conjunción de ambas. Pero es Aristóteles en su Metafísica (libro IV) quien dilucida y precisa el funcionamiento -como una unidad relativa- del principio de contradicción cuando sostiene que "es imposible que lo mismo corresponda y a la vez no corresponda a lo mismo bajo el mismo aspecto" (cit. en Patzig 428). Con esto se puede validar la existencia de una realidad contradictoria que funciona como tal, es decir, que permite la coexistencia de elementos opuestos (dada su naturaleza relativa) y resuelve la contradicción desde la perspectiva hegeliana- de manera dialéctica al generar una nueva unidad conceptual (síntesis) que integraría los dos elementos contrarios iniciales. Al respecto y siguiendo a Hegel, Fouillée afirma que:

la identidad de los contrarios es precisamente el secreto del progreso universal, del pensamiento y de la vida. Pensar, es unir las ideas diferentes y, en definitiva, conciliar los contrarios; vivir, es pasar de un contrario al otro por una acción que domina los dos. Todo progreso es evolución, transformación, movimiento, y todo movimiento, como mostraron Heráclito y Platón, una contradicción realizada [...] La evolución del pensamiento y del ser tiene un ritmo, que es la expresión o símbolo de la razón absoluta: tesis, antítesis, síntesis [...] La tesis llama a la antitesis y ambas se concilian en una síntesis. [En esta] reside, pues, lo racional y lo real: en la armonía o unidad, que es al mismo tiempo la verdad y la vida. (490-491)

En el caso de la novela histórica, ficción e historia se funden pues en un todo propiciando una nueva forma expresiva: la novela histórica. Así, la historia deja de ser exclusivamente archivo, do- 
cumento, inventario de datos, y, la literatura, mera ficcionalidad, imaginario, invención de realidades distintas a lo real para terminar siendo lo uno en lo otro sin exclusión, mas bien con inclusión y alteridad por la presencia ineludible de lo otro.

\section{La ancilaridad}

La novela histórica es pues una "contradicción realizada" en el sentido que la novela en sí no es tan irreal y subjetiva como se piensa y la historia en sí tampoco es tan fáctica y objetiva como se desearía; una y otra contienen elementos imaginados y verdaderos en mayor o menor grado y dimensión cuando operan en conjunción como género único y autónomo al margen de los dos géneros canónicamente establecidos desde la poética aristotélica. En 1944, en su libro El deslinde, Alfonso Reyes llama a este resultado "ancilaridad", porque a veces "puede aparecer en la literatura un fragmento histórico ancilar; a veces, la historia adapta gala literariosemánticas de tipo ancilar” (182). ${ }^{6}$

Teniendo en cuenta criterios de autoridad desde el siglo XIX, el género histórico ha contado siempre en su configuración con hechos impregnados de ficción o supuestos o inventados, por carecer en buena parte y hasta bien entrado el siglo XX de la documentación precisa que fundamente su total veracidad y mucho más cuando se trata de retratos históricos (lo cual es afín psicológicamente a la creación novelística del personaje), de perfiles biográficos o de la descripción de hechos en los cuales participan personajes que dieron lugar a esos hechos, o historias basadas parcialmente en informantes, testigos o interesados de un lado u otro de los hechos que desean participar de la historia relatada. El historiador francés Maurice Agulhon llama a esto "lo verdadero y lo falso en lo general del 'acontecer"' (253-259). Para éste ha habido y hay en

"El concepto de "ancilaridad" proviene de la función de servicio y subordinación frente a la teología que se le adscribía a la filosofía en la Edad Media (ancilla theologiae). Dicha noción va a ser revisada y renovada por Roberto Fernández Retamar en su libro Para una teoría de la literatura hispanoamericana (1985), cuando se reivindica ciertas crónicas de Indias y posteriores, algunos testimonios, proclamas y relatos venidos de la tradición oral, como textos literarios. 
la actualidad historiadores que utilizan "como materia prima tantas mentiras como verdades". Para no pocos historiadores de las ideas o de las mentalidades "una afirmación puede contar más por su contenido mismo, que por su signo algebraico de verdad o error" (253). Lo señalado hoy por Agulhon sirve para avalar lo que hace más de medio siglo Alfonso Reyes señalaba: que los hechos históricos se soportan en su inmediatez, coyunturalidad y en su "suceder real y efímero", igualmente en su mirada "particular y contingente" (176). En consecuencia, es permanente la reescritura e interpretación de la historia acorde con la siempre renovada documentación, los nuevos testimonios, las nuevas tendencias teóricas, metodológicas y relecturas, acorde al desarrollo de las ideas y de la mentalidad del momento. Recurriendo a muchos ejemplos de Estudio de la historia de Arnold J. Toynbee, el ensayista mexicano sostiene que:

en los historiadores clásicos muy a las claras, con más disimulo en los modernos, encontramos el recurso constante a las ficciones para representar lugares y personajes, con descripciones en que hay reflejos imaginados, y con retratos en que parece que presta su pluma el novelista. Los antiguos usaban más liberalmente de tales recursos y en un grado más; pues llegaban a forjar epístolas, discursos y diálogos para expresar el ánimo de los capitanes, los sentimientos populares, el estado de la opinión, en alguna manera breve, simbólica y plenamente expresiva del acto humano.7 Presta servicios eficaces, evoca atmósferas sociales, facilita la exégesis

7 Por ese carácter humano y libertario, Benedetto Croce llama a la historia "hazaña de la libertad" (La historia como hazaña de la libertad 1942) y Max Scheler en Sociología del saber (1936), habla de "la soberana indiferencia de la historia real de las instituciones, acontecimientos, situaciones, para con la historia espiritual y las exigencias de su propia lógica del sentido" (cit. en Reyes 176). Por su estrecha relación de la historia con la literatura, Marcelino Menéndez y Pelayo habla de "La historia considerada como obra artística" (7: 3-30). 
de la realidad [...] Los clásicos dan el edificio; los otros, los andamios, entre los cuales no escasean las vigas inútiles (84).8

Casi toda la literatura clásica, incluso muchas de las mejores novelas del siglo XIX y XX, se construyen con hechos, personajes y acontecimientos históricos. Reyes puede hablar de una "historicidad latente en la novela" (116), porque expresa de una manera explícita o tácita un tiempo (época/s), un espacio (lugar/es) y una circunstancia social (historicidad específica); además, un tiempo y lenguaje propios del momento de aparición de la obra. Aún más, no hay ficción que no se construya con un referente básico en la realidad -no importando la forma o combinación que asuma ésta-. Alfonso Reyes aprecia, en beneficio de la literatura de asunto histórico, que ésta acierta "con una verdad humana más profunda que los inventarios y calendarios históricos" (108). Esto lo lleva a concluir sobre "la naturaleza universal de la literatura, a la vez que su naturaleza ficticia con respecto al suceder real" (183). Y a pesar de que la historia humaniza los conocimientos de las demás disciplinas por ser actos del hombre, la literatura, además, los universaliza al sujetarlos "al orden humano". Como un Midas, agrega Reyes, antropomorfiza "lo extrahumano que adopta bajo su tutela. Y es así, la literatura, el camino real para la conquista del mundo por el hombre" (182). Esta idea no hace más que confirmar lo dicho por

8 Reyes considera que una historia así es más válida que aquella "científica" que se basa en la mera "acumulación de documentos paralelos y superpuestos", y agrega: "no hay mejor documento psicológico sobre Montezuma II y su asco de la codicia ajena que el discurso que le presta Cortés, donde el emperador exquisito, doliente y refinado, acaba por desnudarse para demostrar que no es de oro. Si la historia no recibiera el esfuerzo de la literatura - una vez que pasa de la etapa de la investigación a la etapa de la redacción- nunca lograría ser cosa viva" (84). Por sus virtudes, “antes poéticas que históricas -sostiene Menéndez Pelayo-, viven y vivirán eternamente a los ojos de la memoria la peste de Atenas, la oración fúnebre de Pericles y la expedición de Sicilia, en Tucídides; la batalla de Ciro el joven y su hermano, en Xenophonte [...], la llegada de Agrippina a Brindis con las cenizas de Germánico, en Tácito; la conjuración de los Pazzi y la muerte de Julián de Médicis, en Maquiavelo; la acusación parlamentaria de Warren Hasting, el terrible procónsul de la India, en Lord Macaulay. Con esa le-che ateniense y romana se nutrieron los cinco o seis historiadores españoles que merecen el nombre de clásicos” (18-19). 
Aristóteles (Poética 1451a [36]-1451b [5]) de que la poesía es algo más filosófico y elevado que la historia porque expresa lo universal y lo que debe ser; ella es imitación de la realidad sensible que toma un aspecto espiritual y se eleva hasta ontologizarse; al contrario, la historia es lo particular, expone lo que es, lo que ya sucedió. En la opinión de Djelal Kadir (298), la historia es el dominio del hecho discreto y, por eso delimita, define, es formadora y formativa; en cambio la literatura significa la trasgresión de lo particular y de lo discreto y se orienta a lo universal. Ricœur precisa mejor la idea de Aristóteles cuando afirma que la historia, en la medida en que "se encuentra vinculada a lo contingente, no se encuentra asociada de un modo inmediato con lo esencial, mientras que la poesía, al no estar sujeta al acontecimiento real, puede referirse directamente a lo universal, es decir, a aquello que cierto tipo de personas diría o haría probable o necesariamente", y se pregunta en consecuencia: "¿no podría decirse que, al aproximarse a lo diferente, la historia nos da acceso a lo posible, mientras que la ficción, al permitirnos acceder a lo irreal, nos lleva de nuevo a lo esencial?" (155).

\section{La libertad de los géneros en y antes del romanticismo}

Según Walter Bensant, la literatura contribuye a la historia de dos maneras: la primera, por la pintura y reconstrucción de hechos históricos y de ello podrían dar fe las obras de Daniel Defoe, Fielding, Charles Dickens, Walter Scott (Ivanhoe), entre otros; la segun$\mathrm{da}$, por la interpretación de las inquietudes y maneras de ser y pensar de una época, y a ésta la representan Rabelais (Gargantúa y Pantagrue) con su expresión popular, carnavalesca y paródica y su anticlericalismo; Voltaire con su puesta en duda de la axiología existente; Beecher-Stowe (La cabaña del tío Tom) con su postura antisegregacionista y antiesclavista (cit. en Reyes, 120). Pero es el romanticismo el que abre las puertas al nuevo género con dos reivindicaciones esenciales: la primera, el rechazo a las reglas y distinción de géneros, la lucha por la libertad en el arte y la necesidad de una literatura moderna que responda a los anhelos de la nueva sociedad que se gesta y consolida con la revolución industrial, el advenimiento de la Revolución Francesa y la Ilustración. En el libro de poemas Orientales (1829) observamos cómo Víctor Hugo se pro- 
nuncia por la libertad que es indispensable al genio creador. Para éste no hay buenos ni malos temas para poesía, sino malos poetas. El poeta debe ir donde quiera y hacer lo que le plazca. Esa es la única ley que debe imperar, ya que la poesía debe estar libre de toda sujeción (Michaud 109).

La segunda reivindicación consiste en la necesidad de ampliar el horizonte literario, aceptando las literaturas extranjeras, así como el regreso a las fuentes de inspiración nacional a través de los mitos, las leyendas y las historias locales. El interés por la literatura y la historia cultural extranjera lleva a una toma de conciencia del valor y aportes de esas expresiones y a un cosmopolitismo cultural. Esto valida el principio de que el arte no pertenece a ningún país, de que es heredad de todos y por ende universal. El gusto por lo pintoresco y el color local lleva a la motivación por la historia (medieval cristiana) y a la inquietud por lo social que conducirá, sin equívocos, al realismo, tendencia europea que en América tendrá una vertiente en el costumbrismo o literatura pre-realista, ${ }^{9}$ e igual propensión de los escritores americanos por la historia. Si, como afirma Kadir, "América es la invención del Renacimiento europeo", la historia americana es "la hermenéutica de esa invención" (299). La "invención de América”, de la que Edmundo O’Gorman habla ya en la primera mitad del siglo XX, estaba en el imaginario de los viajeros y comerciantes europeos mucho antes de su descubrimiento, buscando el camino más corto, económico y lucrativo hacia las Indias; también en los libros de viajes y utopías de un Tomás Moro, Campanella, San Agustín y tantos otros (Durán 287-296).

En la literatura latinoamericana la novela histórica tiene, inicialmente, su asiento en la narrativa romántica del siglo XIX ( $\mathrm{El}$ Periquillo Sarniento, Amalia, Facundo, Manuela, etc.) y luego en la realista de la primera mitad del siglo XX, observada en buena parte en los escritores de la Revolución Mexicana y en los dedicados a los temas sociales propios de ese período, es decir, en lo que se deno-

9 La llamo así por el carácter fotografista (estatista, contrario a la verdadera fotografía), por la fragmentación y superposición de cuadros de costumbres y la reproducción mimética de lo observado que niegan la dinamicidad, la interacción espacio-temporal y la verosimilitud de lo narrado, entre otras cosas, propios del realismo. 
minó luego la literatura criollista, mundonovista, neorregional y expresionista, etc. (según la óptica asumida por los respectivos críticos) que centran su temática en la lucha por la tierra o los conflictos sociales derivados de todo tipo de discriminación (asentamiento y explotación de compañías multinacionales, intervencionismo extranjero, militarismo, dictaduras, etc.).

Vale la pena anotar que antes de que el romanticismo apareciera en Europa y aportara la novela histórica, entre otros géneros, ésta ya había dado frutos interesantes en Colombia con dos novelas, El carnero (1636) y El desierto prodigioso (1673), redescubiertas en 1859 y 1962, respectivamente. El crítico de literatura colonial Héctor Orjuela anota, sobre la primera, que si bien algunas obras coloniales "son importantes anticipos del género narrativo en Hispanoamérica y, en especial, de la novela, ninguna alcanza la trascendencia de El carnero" (55); es "un roman à clef de la sociedad neogranadina" y "verdadera comedia humana de los años coloniales" (49); afín opinión se observa en Anderson Imbert para quien Freyle es "el primer cuentista de la colonia" y El carnero "fuente de la literatura costumbrista e histórica del siglo XIX" y "un libro originalísimo [porque] nos da, en prosa impávida y sin afeites, pasajes que tienen valor de novela" (123). Para Oscar G. Ramos es el "libro único de la colonia" y "tesoro singular de la literatura colonial hispanoamericana" (31), y Camacho Guizado reconoce que es un texto de "posibilidades literarias, de virtualidades novelísticas" (149). Ya en 1935 el historiador literario Gustavo Otero Muñoz había observado en El carnero el rasgo peculiar de novela histórica por su "carácter novelesco-anecdótico, sin que pueda clasificarse entre las rigurosamente históricas, pues no siempre se ciñe a la verdad" (1937). Otero califica a Freyle como "el más ameno novelador de la historia colombiana" (idem).

Mientras que algunos consideran El carnero como un "libro de excepcional valor histórico" (cit. en Orjuela 52), otros lo destacan por sus elementos narrativos, ficcionales o la combinación lograda pa-ra su tiempo y a la vez modélica- de ambos géneros (idem). Pero es Ramos quien le otorga un calificativo híbrido al texto de Freyle, llamándolo "historiela", porque no es ortodoxamente ni historia ni novela, sino una mezcla de ambos. Afirma al respecto: "ni historias ni leyendas, sino hechos presumibles de historicidad, tal vez tejidos 
con leyendas y matizados por el genio imaginativo del autor que toma el hecho, le imprime una visión propia, lo rodea con recursos imaginativos y, con agilidad, le da existencia a un relato corto" (34).

No importa a cuál novela histórica nos refiramos, la del pasado o la del presente, la literatura latinoamericana -para sólo hablar en particular de ésta- ha servido y servirá a una ingente y significativa tarea mientras la patria una y múltiple de nuestra América siga enajenada y expuesta como un Prometeo a su desventración y sevicia, y esa tarea, "gigantesca tarea", dirá sentenciosamente Carlos Fuentes, es la de "darle voz a los silencios de nuestra historia, en contestar con la verdad a las mentiras de nuestra historia, en apropiarnos con palabras nuevas de un antiguo pasado que nos pertenece e invitarlo a sentarse a la mesa de un presente que sin él sería la del ayuno" (cit. en Kadir 300).

Habiendo leído o no a Bajtín (cf. Estética 248-254), cuando sostiene que la historia es un género discursivo ${ }^{10}$ como lo es la novela, Fuentes retoma esta idea cuando dice que "la historia es, finalmente, una operación del lenguaje: sabemos del pasado y sabremos del presente, lo que de ellos sobreviva, dicho o escrito. La historia de América Latina parece representada por un gesticulador del mundo. Adivinamos en las muecas y manotazos del orador una alharaca de discursos grandilocuentes, proclamas y sermones, votos piadosos, amenazas veladas, promesas incumplidas y leyes conculcadas. Escuchamos en vano silencio" (cit. en Kadir 300).11

${ }^{10}$ Kadir, basado en la cita de Fuentes y quizá en Bajtín que no menciona, opina que la historia y lo histórico se originan en hechos que dependen del lenguaje y de las posibilidades del lenguaje para su concreción; "en esa medida el hecho historiado es poética discursiva, es decir, tropos. Para nuestra civilización y su inexorable dependencia de la palabra escrita, literatura e historia conjugan y conjuegan en el ámbito de la escritura" (297). La historia y la novela, aunque pertenecen a distintos dominios de la cultura, comparten en común el lenguaje por ser formas discursivas. "El novelar y el historiar son equivalencias del tramar, es decir, de decisión poética” (298).

${ }_{11}$ Fragmentos del discurso de Fuentes, en Caracas, con motivo de haber recibido el premio "Rómulo Gallegos" por su novela Terra nostra. 


\section{Historia y narratividad en Ricœur: teoría del discurso narrativo}

En Tiempo y narración (1987), Ricœur dedica en cada uno de los tomos de esta importante obra algún aparte para mostrar la íntima relación entre la historia y la ficción con la tesis de que cualquier historia, aún "la más alejada de la forma narrativa sigue estando vinculada a la comprensión de la narrativa por un vínculo de 'derivación' (1: 165); así, el saber histórico procede de la comprensión narrativa sin que pierda su carácter científico (166). Dicha tesis la valida Ricœur con dos convicciones: la primera, que no es posible ya "vincular el carácter narrativo de la historia a la supervivencia de una forma particular de la historia, la historiografía", es decir, que no se debe confundir el carácter narrativo último de la historia con la defensa de la historia narrativa. La segunda convicción es que "si la historia rompiese todo vínculo con la capacidad básica que tenemos para seguir una historia y con las operaciones cognitivas de la comprensión narrativa [...], perdería su carácter distintivo en el concierto de las ciencias sociales: dejaría de ser histórica" (165). Es claro para el pensador francés que la inserción de la historia en el dominio de la acción y vida humana y su temporalidad (construcción del tiempo histórico) "ponen en juego la cuestión de la verdad en historia" y ésta es inseparable de lo que él llama la "referencia cruzada' entre la pretensión de verdad de la historia y de la ficción" (167).

Ricœur reconoce que el vínculo entre historia y narración fue consecuencia de dos corrientes de pensamiento: el modelo monológico y la filosofía analítica. El primero considera la narración como una forma demasiado elemental de discurso para satisfacer las exigencias de explicación y cientificidad que se requieren; para este modelo "la narración sólo tiene un carácter episódico y no configurador". La segunda, re-evalúa el relato y sus recursos de inteligibilidad e "intenta indagar en qué medida nuestros modos de pensar y de hablar a propósito del mundo implican frases que emplean verbos en tiempo pasado y enunciados irreductiblemente narrativos" (I: 243).

Ricœur media con una propuesta articuladora entre historia y ficción y la precisa con los términos de convergencia y entrecruzamiento de ambas nociones. Para explicar la primera acude a la 
aplicación de la teoría de la recepción, cuyo momento fenomenológico es el acto de lectura, es decir, la lectura crea un espacio común para los intercambios entre la historia y la ficción; somos lectores tanto de novelas como de historias. El entrecruzamiento se da luego del paso de la convergencia y se entiende como "la estructura fundamental, tanto ontológica como epistemológica, gracias a la cual la historia y la ficción sólo plasman su respectiva intencionalidad sirviéndose de la intencionalidad de la otra" (3: 902), es decir, que la historia se sirve de la ficción para refigurar el tiempo histórico y la ficción se sirve de la historia para el mismo fin, refigurar el tiempo humano. "Esta concretización mutua marca el triunfo de la noción de figura, bajo la forma del 'figurarse que..." (idem).12 En otros términos, lo ficcional, lo imaginario, lo novelado se incorpora en la perspectiva del pasado del haber-sido -no observable-, sin debilitar su perspectiva realista ("simetría entre pasado 'real' y mundo 'irreal"' 903).

\section{El universo literario y la nueva historia}

Si bien hemos intentado demostrar la interacción e inseparabilidad de la ficción y la historia en la novela histórica desde historiadores

12 Ese "figurarse que...", como función representativa de la imaginación histórica que es, corresponde a aprender a "ver como trágico, como cómico, etc. cierta concatenación de acontecimientos" (3: 908). Es la manera de aprender a ver el pasado, así, entonces, "se puede leer un libro de historia como una novela". El acoplamiento de la ficción con la historia no debilita la representación de esta última, sino que contribuye a realizarla en la opinión de Ricœur.

Es precisamente en el acto de lectura que, según Ricœur, se "instituye la relación de complicidad entre la voz narrativa y el lector implicado". En virtud de dicho pacto el lector suspende el recelo, se fía y permite al historiador el derecho "de conocer las almas. En nombre de este derecho, los historiadores antiguos no dudaban en poner en labios de sus héroes discursos inventados que los documentos no garantizaban, sino que hacían sólo plausibles. Los historiadores modernos ya no se permiten estas incursiones fantásticas, en el sentido propio del término. Sin embargo, recurren, bajo las formas más sutiles, al genio novelesco, puesto que intentan reefectuar, es decir repensar, cierto cálculo de fines y medios. El historiador no se prohíbe, pues, 'pintar' una situación, 'expresar' una sucesión de pensamientos y conferirle la 'vivacidad' de un discurso interior” (908909). 
y ensayistas literarios y desde la filosofía misma, es importante rastrear las opiniones al respecto de los mismos historiadores contemporáneos. Los nuevos historiadores, a diferencia de los tradicionales y decimonónicos, reconocen la importancia de otras disciplinas, entre ellas la literatura, en la construcción de la nueva historia que es parte esencial de la cultura; así lo considera Jacques Le Goff cuando señala que "la historia de las mentalidades no puede construirse sin estar estrechamente asociada a la historia de los sistemas culturales, de los sistemas de creencias, de los valores de equipamiento intelectual, en los cuales ha sido elaboradas, han vivido y evolucionado" (cit. en Céar 227). Por eso, en la opinión del historiador Flandrin (214), no podría hablarse de un hombre natural -tampoco de una historia natural, es decir, sin sedimento en el pasado ni ajeno a otros discursos-, porque todo comportamiento humano -al igual que la historia- "ha sido moldeado por la cultura" que es hecho acumulativo, consecutivo (diacrónico), pero también estructura sincrónica del pasado y "ha sido marcada por las estructuras y los traumatismo de éste". Agrega Flandrin: "a través de la literatura, la moral, el derecho, la lengua, las ciencias, inclusive las técnicas y las artes, en suma, de todo lo que constituye nuestra cultura, hemos sido subrepticiamente invadidos, desde nuestro nacimiento, por el pasado" (idem).

La presencia de la ficción en la historia no es asunto sólo del presente, sino que ha estado ligada desde el comienzo de la aparición de ambos géneros, aunque sea la literatura más originaria y la que da lugar a la historia en la reconstrucción de hechos, formas de vida y mentalidades, perfiles de personajes, fundaciones reales o míticas (mediante cosmogonías), configuración del orden de lo cotidiano (comidas, vestidos, modas, gustos, vivienda, intercambio social y económico, etc.). Así lo estima el historiador francés Charles-Oliver Carbonell cuando sostiene que: "la nueva historia no es la única forma de hacer historia, ya que otras corrientes más antiguas que ella subsisten y prosperan: la historia narrativa, la historia positiva, la historia erudita” (246). En el afán del rigor, de la sistematicidad, de la ortodoxia, de conservar y reproducir las formas canónicas, muchos historiadores terminan olvidando lo esencial humano, o como lo dice Carbonell, no sin ironía: "les fascinan los archivos e incluso el polvo. Durante largo tiempo nos hemos pre- 
ocupado por las huellas, incluso, por las huellas de las huellas. Pero a menudo olvidamos que detrás de éstas se encuentra al hombre" (249).

En el libro Introducción a la historia, Marc Bloch se formula la pregunta: ¿Para qué sirve la historia?, y años después Pierre Chaunu responde: “Para vivir, para ser y para existir!” (11). La contundencia de esta afirmación evita cualquier equívoco con respecto a la naturaleza vital, humana y humanística de este género y de esta propuesta de lectura de la realidad pasada, presente y aún futura. Por eso se puede afirmar que ninguna sociedad verdaderamente humana ha podido sobrevivir sin lo que Chaunu llama la "función historiadora" (12) que supone, además del dominio de la escritura, del universo mítico de la tradición popular (función mitográfica), de la sedimentación cultural y de "un mundo ya desencantado" (idem), es decir, sólo nos apropiamos de una pequeña parcela de la historia real, lo demás, como valor agregado, lo pone a funcionar el sujeto indagador (historiador y/o novelador) con su acerbo cultural, la puesta en función de la imaginación, de la intuición y de una buena capacidad de relación e inferencialidad. Por eso aquí no funcionan conceptos absolutos de nada, mas sí la idea comprehensiva de Gadamer cuando afirma que "en todo conocimiento histórico anida un 'comprender"' (Koselleck 103).13 Por pertinente, viene bien el concepto de imaginación propuesto por Ricœur cuando dice que ésta consiste en

el juego libre de las facultades, que se desarrolla, al mismo tiempo, conforme a la libertad de invención y a un extraño sentido del orden que Kant llama la 'legalidad sin ley', que se encuentra bajo la influencia de la 'finalidad sin fin del juicio reflexionante. Las 'variaciones imaginativas' propias del nú-

13 Siguiendo a Gadamer, Koselleck considera que la historia como la teología, la jurisprudencia, la poesía y su interpretación, son formas para "el comprender existencial" y agrega: "la historia como ciencia de la historia y como arte de su representación o narración, es parte del cosmos hermenéutico proyectado por Gadamer. A través del escuchar, del hablar y de los textos, también el historiador se mueve sobre la misma plataforma sobre la cual se mueven las otras figuras paradigmáticas de la hermenéutica gadameriana: el teólogo, el jurista y el exégeta de la poesía" (69). 
mero infinito de historias contadas por la humanidad, así como su sumisión espontánea a una serie de configuraciones recurrentes, constituyen, sin duda alguna el mejor ejemplo de esta creatividad regulada (150).

Toda lectura de la vida de los hombres y del universo es ineludiblemente selectiva, susceptible y necesaria de complemento en el tiempo. "La ambición de la totalidad es noble -afirma al respecto Chaunu-, pero el sueño de la historia total es absurdo y anticientífico. La elección es siempre arbitraria y reveladora. La historia, incluso más que la memoria, elimina para recordar. Sólo se salva una parte infinitesimal de lo vivido, un esquema, algunas referencias, conceptos, tendencias, ciertos modelos y la medida teórica del tiempo" (13).

La historia no nace con el universo porque no necesita de ella para ser reconocido, nace con el hombre que requiere urdir ese tejido al saberse temporal y efímero. Ante la proximidad y el acecho del olvido, el hombre urde la memoria y con ella la historia para alejar, aunque sea fugazmente, la sombra de la muerte y con ella el propio vacío como presencia histórica. Y de esto da cuenta ejemplar y modélicamente la literatura, y sólo la literatura, y en particular la poesía y la novela. Razón tiene Gadamer cuando sostiene que "el fundamento de la civilización humana no es la matemática, sino la constitución lingüística de los hombres [...] El hombre instituye los nombres para todo, tal como se decía en el Antiguo Testamento, y a los ojos de esta narracción se embarca -tras el pecado original- en una empresa contraria a Dios" (116-117).

Chaunu utiliza una imagen para explicar el eterno presente de la historia, que paradójicamente es, al instante, hecho del pasado y, a la vez, presente por su contante actualización y presencialidad cuando la invocamos: "el campo barrido cambió y no ha cesado de cambiar. La historia, reflejo del presente más que del pasado, tiene por misión suministrar a nuestra memoria cultura e inteligencia, aquellos alimentos que ella misma precisa" (idem), y agrega de manera categórica: "el conocimiento de lo cambiante es el mejor medio para preparar el 'zócalo de lo permanente'. Y es sobre éste que se construye la historia" (16). En este mismo sentido Philippe Ariés (202-204) se pronuncia a favor del cambio permanente en la 
historia, del momento en que el sentido cambia. La historia no debe ser algo estático, definido de antemano, previsible, cuantificable; "hay que poner el acento en el movimiento, incluso cuando es tan lento que apenas se percibe o cuando hay etapas muy espaciadas" (idem). También se declara en contra de explicaciones, de causalidades únicas de la historia. Para él la primera causa del cambio es el cuestionamiento de cualquier determinismo, llámese marxismo o el neopositivismo científico o técnico. Al rechazar la idea de un único sentido de la historia, pone en cuestión la idea de evolución por "sospechosa o por lo menos inútil", y hasta el concepto de cambio se ve afectado "de contagio" y tanto mejor si se puede prescindir de él. La salida al "debilitamiento" de todos estos determinismos es sustituirla "por un principio de pluricausalidad".

Para Ariés, "la hipótesis de un movimiento continuo implica otra hipótesis: la de un motor que impulsa al sistema. Pensamos que no existe un solo motor sino varios. Pero un fenómeno que se explica por un gran número de causas - cinco o seis- no es explicado en absoluto, y pierde sentido" (204). En este sentido lo que mejor responde a esta especie de polisemia en la necesidad de comprender es lo que él llama la "etnología estructuralista" o "segunda razón del cambio de curso en la historiografía” (203). El etnógrafo estructuralista aconseja no fatigarse "buscando una genealogía para cada fenómeno. El origen no tiene importancia, pues cuando cambia un sistema se modifica el sentido, al igual que ocure con las palabras. Su nuevo sentido no depende demasiado del que lo precedió y en todo caso menos que de su coexistencia en el nuevo sistema. Lo importante es pues, la lógica del sistema y ésta no siempre se percibe a primera vista. El historiador es quien debe encontrarla" (204). Igual ocurre con el crítico frente al texto literario o de otra naturaleza discursiva, es decir, percibir no lo que se muestra en la superficie, sino las redes que entretejen las distintas prácticas discursivas y sus puntos de articulación que forman un todo sistemático imbricado que autogeneran sentidos diversos.

No han sido pocas las veces que Chaunu ha repetido que la "historia no debe vacilar en definirse como una ciencia auxiliar de todas las disciplinas" (13), particularmente de las ciencias humanas, porque provee de dos recursos fundamentales: las historias de hechos y de vidas captadas desde múltiples ángulos y formas ex- 
presivas: el lenguaje y la escritura. Chaunu no hace otra cosa que poner en evidencia la escisión, histórica y académica, durante siglos, de la historia institucional con respecto a otros dominios de la cultura. Le Roy-Ladurie confirma al respecto cuando sostiene que: "debemos reconocer, por cierto, que entre nosotros los historiadores es común cierta ignorancia de los problemas culturales" (184). Las palabras de Ricœur son oportunas para mostrar el grado de imbricación de la historia y la ficción y cómo una se manifiesta en la otra o recíprocamente cuando confluyen en la novela histórica. ${ }^{14}$ Una misma obra puede ser una gran novela y un gran libro de historia y leerse en un sentido u otro o como conjunto armónico como, por ejemplo, La guerra y la paz de Tolstoi o la descripción de la Historia de la revolución francesa de Michelet (1963). Afirma Ricœur: "Lo que constituye precisamente la perennidad de ciertas grandes obra históricas, cuyo progreso documental ha comprometido, sin embargo, la fiabilidad propiamente científica, es el carácter perfectamente apropiado de su arte poético y retórico a su manera de ver el pasado" (3: 909).

Siguiendo una idea propuesta por el historiador alemán Reinhart Kosselek, en un debate sobre la teoría de la historia, de que la historiografía moderna debe darse cuenta que "la oposición clásica 'res fictae', 'res factae' es una provocación para los historiadores" y que "el descubrimiento moderno de un tiempo específicamente histórico obliga al historiador a adoptar -respecto de los hechosla perspectiva de la ficción cuando intenta reconstruir un pasado desaparecido" (cit. en Jauss 139), Jauss se afirma en la convicción de que no es posible lograr una representación de los hechos (res factae) al margen de toda ficcionalización (res fictae). Se da un anclaje entre los dos de manera que permite su coexistencia y retroalimentación. Ambas funcionan como la forma y el sentido o el significante y significado en el habla. ${ }^{15}$ De ahí su idea, desde la hermenéu-

14 Ricœur estima que la ficción presenta rasgos que favorecen su "historización", por eso sostiene que "el relato de ficción 'imita', en cierto modo, el relato histórico. Narrar cualquier cosa es narrarla como si hubiese acontecido" (913).

15 Y agrega al respecto: "se trata del prejuicio que lleva a creer que los 'res fictae' son separables como el fondo y la forma, el acontecimiento histórico y el ornamento retórico, como si un elemento pudiera ser desprendido de sus fuen- 
tica, que "al reconocer el papel de los 'res fictae' en la constitución del sentido de cualquier experiencia histórica, el historiador sabe que está forzado a aplicar los recursos de la ficción, incluso si por un arraigado prejuicio hubiese, durante mucho tiempo, subestimado su papel en el conocimiento y la descripción" (idem). En el curso de este proceso, desaparece la dicotomía clásica de los 'res fictae' como propios del ámbito de la poesía, y de los 'res factae' como objetos de la historia. La ficción poética se convierte en el horizonte de la realidad, en tanto que la realidad histórica se torna en el horizonte de la poesía. En lo sucesivo 'la verdad específica de la poesía' deja de ser algo más que aquella verosimilitud en la cual, desde Chladenius, la historia podía percibir una de las formas históricas de la verdad. Al mediatizar la oposición ente ficción y verdad, la verosimilitud crea al mismo tiempo la función cognitiva y comunicativa de lo ficticio. ${ }^{16}$ La poética -desde Diderot y Lessingy la doctrina histórica de la Ilustración, reactualizan la noción de lo verosímil que se convierte, entonces, en el engranaje común entre poesía e historiografía.

Concluyamos provisionalmente este alegato señalando que la novela histórica es, ante todo, género discursivo y participa en igualdad de condiciones de la mitografía (invención e imaginación creadora humana) y de la historia (realidad fáctica) que no es otra cosa que un preguntarse por la múltiple realidad con rasgo humano. La función de la literatura como la de la historia, independientes una de otra o articuladas en un nuevo género no tienen otra razón de ser, o incumbe a su naturaleza la pregunta por el ser de la

tes en toda su pureza y objetividad, esto es, como si los medios estéticos utilizados a regañadientes por el historiador científico sólo entraran en juego en un segundo plano, el de la trascripción de los hechos en una narración” (139-140). $\mathrm{Y}$ fue precisamente la reflexión hermenéutica, según Jauss, la que acaba con este prejuicio al tomar conciencia que "los 'res fictae' no constituyen un elemento primario [prescindible o borrable] sino un resultado, y que los actos que lo conforman y que fundamentan su significación, presuponen formas elementales de visión y representación" (140).

16 Según Jauss, en la medida en que está determinada por la totalidad (comienzo, desarrollo y fin de una fábula), "la narración está históricamente precedida por toda una gama de formas de comunicación preliterarias, definibles por diversos modi dicendi (citar, testimoniar, proclamar, convencer, demostrar, etc.)" (151). 
cosa, así lo entiende Raymond Weil cuando al igual que Fernand Braudel (1982)17 o Pierre Chaunu se formulan el por qué de la historia, y para responder a tal interrogante deben remontarse necesariamente al origen y a la evolución natural de los géneros, es decir, al primer gran género, al literario de las epopeyas. Así da cuenta Weil de la pregunta formulada:

la epopeya -que por lo demás contaba la historia a su manera- un buen día habría dado paso a la narración en prosa, y quizás, por relevo de una forma fotográfica, a la narración de viajes. La poesía didáctica habría contribuido, la de Hesíodo, al igual que la curiosidad excepcional que impulsa a las personas, a interrogarse y a preguntar por el otro, a su extraordinaria facultad de maravillarse, este es el primer sentido de la 'historia': interrogación, pregunta (25).

Por su nueva o segunda naturaleza la novela histórica demanda, desde la literatura y desde la historia, un doble interrogante ante la realidad y la esencialidad de las cosas y los seres. Una idea de Hannah Arendt, retomada por Ricœur, sirve para concluir esta inicial reflexión: "frente a la fragilidad de las cosas humanas, el relato devela el ‘quien' de la acción, lo expone en el espacio de aparición del reino público, le confiere una coherencia digna de ser contada, y finalmente le garantiza la inmortalidad de la fama"18 (3: 911). ${ }^{19}$ Pero siglos antes, Schiller descubre en el drama histórico la ley de la armonía estética cuando él mismo lo concibe como un "punto

${ }_{17}$ Braudel responde a la pregunta del por qué de la historia en su Lección Inaugural al Colegio de Francia en 1950 y sostiene, además, que "todas las ciencias se interesan por un único y común paisaje: el de las acciones pasadas, presentes y futuras del hombre" (201-202). Pregona por la necesidad de "romper las fronteras entre especialistas" (182-184) y "a favor de un diálogo de la Historia y de las ciencias humanas" (179-182).

18 H. Arendt, The human condition. Chicago: University of Chicago Press, 1958.

19 Ricœur le atribuye al relato de ficción una condición cuasi histórica y a la historia de cuasi ficción. El primero lo es en "la medida en que los acontecimientos irreales que relata son hechos pasados para la voz narrativa que se dirige al lector; por eso, se asemejan a acontecimientos pasados, y por eso, la ficción se asemeja a la historia" (3: 914). 
de intercesión entre el drama de la pasión individual y el drama de la plaza publica” (cit. en Menéndez 15). ${ }^{20}$

\section{Bibliografía}

Agulhon, Maurice. "Algunas reflexiones sobre lo verdadero y lo falso." Gadoffre, Certidumbres 251-262.

Anderson Imbert, Enrique. Historia de la literatura hispanoamericana I.

La colonia, cien años de la república. $2^{\mathrm{a}}$ ed. corr. y aum. México:

Fondo de Cultura Económica, 1970.

Ariés, Philippe. "La sensibilidad al cambio en la problemática de la historiografía contemporánea." Gadoffre, Certidumbres 199-204.

Aristóteles. Retórica. 2a. ed. Tr. Francisco de P. Samaranch. Madrid: Aguilar, 1968.

—. La Poética de Aristóteles. Tr. Valentín García Yebra. Madrid: Gredos, 1974.

Bajtín, Mijaíl. Estética de la creación verbal. Tr. Tatiana Bubnova. México: Siglo XXI, 1982.

Bloch, Marc. Introducción a la historia. México: FCE, 1992.

Boves Naves, María del Carmen. La novela. Madrid: Síntesis, 1993. Braudel, Fernand. La historia y las ciencias sociales. 6a. ed. Tr. Josefina Gómez Mendoza. Madrid: Alianza, 1982.

Camacho Guizado, Eduardo. "Juan Rodríguez Freyle." Historia de la literatura latinoamericana I. Coord. Luis Iñigo Madrigal. Madrid: Cátedra, 1982. 145-150.

${ }^{20}$ Evaluando y relacionando los grandes ejemplos de la historia clásica de la antigüedad, Menéndez Pelayo observa que la historia se construía en una "unidad orgánica tan vigorosa como la de un poema o novela". Ante todo se veía la vida humana como un drama y el historiador aspiraba a reproducirla, por eso, añade Menéndez: "no le basta al historiador clásico que los personajes hablen con la voz de sus hechos; no le basta presentarlos vivos y en acción; quiere trasladar al papel lo más recóndito de su conciencia, y mostrarnos el laboratorio de los misterios psicológicos. Cartas que no escribieron, discursos que no pronunciaron, inadmisible en otro genero de historia, pero forzoso en ésta -novela histórica-, viene a darnos en forma puramente artística la noción del carácter y el desarrollo de la pasión. Así se funden armoniosamente ciencia y arte. El historiador se lanza al mundo poético de los verosímil, en aras de lo verdadero" (17). 
Carbonell, Charles-Oliver. "El aporte de la historia a la historiografía." Gadoffre, Certidumbres 243-249.

Carpentier, Alejo, Emir Rodríguez Monegal y otros. Historia y ficción en la narrativa hispanoamericana. Caracas: Monte Ávila, 1984.

Céar, Jean. "El aporte de la historia cultural: un ejemplo de investigación." Gadoffre, Certidumbres 223-235.

Chaunu, Pierre. "Prefacio." Certidumbres e incertidumbres de la historia. Bogotá: Norma-Universidad Nacional, 1997. 11-16.

Colingwood, R.H. La idea de la historia. $3^{\mathrm{a}}$ ed. México: Fondo de Cultura Económica, 1952.

Croce, Benedetto. La historia como hazaña de la libertad. México: Fondo de Cultura Económica, 1942.

Durán, Manuel. "Notas sobre la imaginación histórica y la narrativa hispanoamericana." Carpentier, Historia 287-296.

Fernández Retamar, Roberto. Para una teoría de la literatura hispanoamericana. Bogotá: Instituto Caro y Cuervo, 1985.

Flandrin, Jean-Louis. "De la historia-problema a la aproximación histórica de los problemas." Gadoffre 207-218.

Fouillée, Alfredo. Historia general de la filosofía. 2a ${ }^{a}$ ed. aum. Tr. del francés Gallac Palés. Buenos Aires: Anaconda, 1943.

Gadamer, Hans-Georg. Verdad y método. 4a. ed. Tr. del alemán. A. Agud y R. de Agapito. Salamanca: Sígueme, 1991.

Gadoffre, Gilbert, ed. Certidumbres e incertidumbres de la bistoria. Bogotá: Norma-Universidad Nacional, 1997.

Garasa, Delfín Leocadio. Los géneros literarios. Buenos Aires: Columba, 1971.

González O., César. "La interpretación y la historia." Aproximaciones. Lecturas del texto. Ed. Esther Cohen. México: UNAM, 1995. 95-115

Huizinga, J. El concepto de la historia y otros ensayos. México: Fondo de Cultura Económica, 1946.

Jauss, Hans-Robert. "Experiencia histórica y ficción.” Gadoffre, Certidumbres 139-156.

Jitrik, Noé. Historia e imaginación literaria. Las posibilidades de un género. Buenos Aires: Biblos, 1995.

Kadir, Djelal. "Historia y novela: tramatización de la palabra." Carpentier, Historia 297-307. 
Kosseleck, Reinhart y Hans-Georg Gadamer. Historia y hermenéutica.

Tr. del alemán Faustino Oncina. Barcelona: Paidós, 1997.

Lukács, Georg. La novela histórica. Tr. del alemán Manuel Sacristán.

México: Grijalbo, 1976.

Marx, Carlos y Federico Engels. Sobre arte y literatura. Bogotá: La Oveja Negra, 1972.

Menéndez Pelayo, Marcelino. Estudios y discursos de crítica bistórica y literaria. Santander: Consejo Superior de Investigaciones Científicas, 1942. Vol. 7 de Obras completas. 65 vols. 1940-1959.

Menton, Seymour. La nueva novela histórica de la América Latina, 1979-1992. México: Fondo de Cultura Económica, 1993.

Michaud, Guy y Paul Van Tieghem. Le romantisme. Paris: Hachette, 1959.

O'Gorman, Edmundo. La invención de América: investigación acerca de la estructura histórica del Nuevo Mundo y del sentido de su devenir. México: Fondo de Cultura Económica, 1986.

Orjuela, Héctor H. Literatura hispanoamericana. Ensayos de interpretación y de crítica. Bogotá: Instituto Caro y Cuervo, 1980.

Otero Muñoz, Gustavo. Resumen de bistoria de la literatura colombiana. 2a. ed. Bogotá: ABC, 1937.

Patzig, Günther. "Contradicción." Hermann Krings y otros. Conceptos fundamentales de filosofía I. Tr. Raúl Gabás. Barcelona: Herder, 1977, p. 425-434.

Ramos, Oscar Gerardo. "El Carnero, libro único de la colonia." Juan Rodríguez Freyle. El carnero. Medellín: Bedout, 1973.

Reyes, Alfonso. El deslinde. Prolegómenos a la teoría literaria. México: Fondo de Cultura Económica, 1983.

Ricœur, Paul. Tiempo y narración I. Configuración del tiempo en el relato bistórico. 2a. ed. Tr. Agustín Neira. México: Siglo XXI, 1998.

- Tiempo y narración III. El tiempo narrado. 2a. ed. Tr. Agustín Neira. México: Siglo XXI, 1999.

- Historia y narratividad. Tr. Gabriel Aranzueque. Barcelona: Paidós, 1999.

Roy-Ladurie, Emmanuel Le. "Algunas orientaciones de la Nueva Historia.” Gadoffre, Certidumbres 173-192.

Weil, Raymond. "Nacimiento y muerte de la verdad histórica de la antigua Grecia." Gadoffre, Certidumbres 25-35. 
White, Hayden. El contenido de la forma: narrativa, discurso y representación. Traducido del inglés por Jorge Vigil Rubio. Barcelona: Paidós, 1992.

Wellek, René. Historia de la crítica moderna 1750-1950. El romanticismo. Tr. J. C. Cayol de Bethencourt. Madrid: Gredos, 1959. 
